Journal of Engineering and Applied Sciences 14 (9): 2764-2774, 2019

ISSN: 1816-949X

(C) Medwell Journals, 2019

\title{
Design and Simulation of Zeta Converter with ZVZCS Switching Technique
}

\author{
A. Amudha, M. Siva Ramkumar and M. Sivaram Krishnan \\ Karpagam Academy of Higher Education, Department of Electrical and Electronics Engineering, \\ Karpagam University, 641021 Coimbatore, India
}

\begin{abstract}
This study deals with the design of Zeta converter with ZVZCS switching technique for better efficiency, lower total harmonic distortion factor and power factor correction. It requires simpler control circuitry with fewer external components added with SEPIC converter. The basic operation of Zeta converter is explained and PI filter is used to reduce the harmonics. Like SEPIC DC/DC converter topology, the Zeta converter topology also provides a positive output voltage from an input voltage for boost and buck purposes. Inverse of Cuk converter. ZVZCS switching technique is used to reduce the THD. The performance of Zeta converter in open loop and closed loop is obtained using MATLAB Simulink. Zeta converter in closed loop shows better performance than open loop. The performance of Zeta converter is compared by comparing both open loop and closed loop. Zeta converter in closed loop has low THD value and power factor near to unity.
\end{abstract}

Key words: Zeta converter, THD (Total Harmonics Distortion), PFC (Power Factor Correction), ZVZCS (Zero Voltage Zero Current Switching), MATLAB Simulink, performance

\section{INTRODUCTION}

The traditional technique for AC-DC change utilizing an uncontrolled rectifier with one capacitor is not utilized as a part of because of issues, harmonic injection into $\mathrm{AC}$ control supply, poor power factor, high peak current, line voltage distortion, expanded EMI, additional burden and losses on lines. The advancement of power electronics of solid-state switch mode amendment converters has achieved an unmistakable level for enhancing power quality issues in the terms Power-Factor Correction (PFC) and reduced Total Harmonic Distortion (THD). The typical DC-DC converter topology utilizes boost converter, buck- converter, buck-boost converter, SEPIC and Cuk converter have their extraordinary constraints when they were utilized for a dynamic PFC alongside voltage regulation issues ( $\mathrm{Hu}$ and Gong, 2015; Govindaraju et al., 2017; Koutroulis and Blaabjerg, 2012; Tao et al., 2008; Erickson and Maksimovic, 2007; Amudha et al., 2017a, b; Ramkumar et al., 2017a, b; Ramkumar, 2017).

In the proposed Zeta converter moderately new class of DC-DC converter is utilized for dynamic PFC and voltage direction. The value of being a segregated circuit, can work as both step up voltage and step down voltage of converter and having single stage (Govindaraju et al., 2017).

\section{MATERIALS AND METHODS}

Zeta converter: Power handling for both voltage regulation and power factor correction. The Zeta converter plays out an operation of non-modifying buck-boost similar that of a DC-DC SEPIC converter. But an application which requires more power, then the operation of a SEPIC converter is irregular mode. It is not alluring in light of the fact that it brings about high Root Mean Square (RMS) estimations of the currents creating elevated amounts of worry in the thyristor. In this proposed concept, a dynamic $\mathrm{PFC}$ is performed by utilizing a DC-DC Zeta converter working in Continuous Conduction Mode (CCM) where the furthermore included inductor current will take after the sinusoidal voltage waveform (Subramanian et al., 2017; Prabha et al., 2017; Yuvaraj et al., 2017; Ravichandran et al., 2017; Latha et al., 2017; Sivakumar et al., 2017; Krishnan et al., 2017; Kumar et al., 2016; Krishnan and Ramkumar, 2016) (Fig. 1).

Principle of operation: Examining on DC-DC converter Zeta waveforms it demonstrates that at equilibrium inductors $\mathrm{L}_{1}$ normal current equivalents $\mathrm{I}_{\mathrm{IN}}$ and inductor $\mathrm{L}_{2}$ normal current equivalents output current IOUT, since, the i DC current through the flying capacitor CFLY is additionally same. Likewise there Stage- $1\left[\mathrm{M}_{10 \mathrm{~N}}\right]$.

The switch's $M_{1}$ is in the ON state, so that, the voltages of $V_{L 1}$ and $V_{L 2}$ are equivalent to $V_{\text {in }}$. In this day and age at interval Diode $D_{1}$ is in OFF state with a switch

Corresponding Author: M. Siva Ramkumar, Karpagam Academy of Higher Education,

Department of Electrical and Electronics Engineering, Karpagam University, 641021 Coimbatore, India 


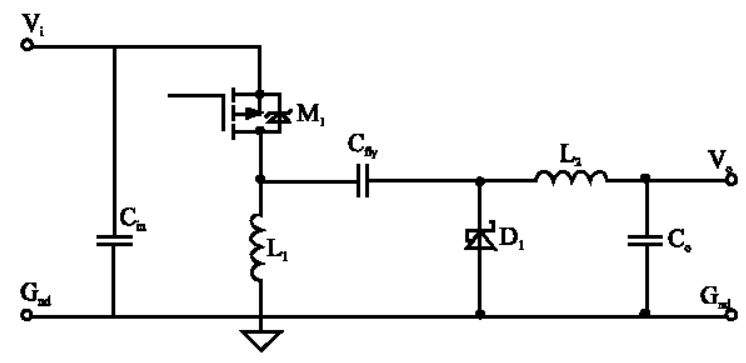

Fig. 1: Zeta converter

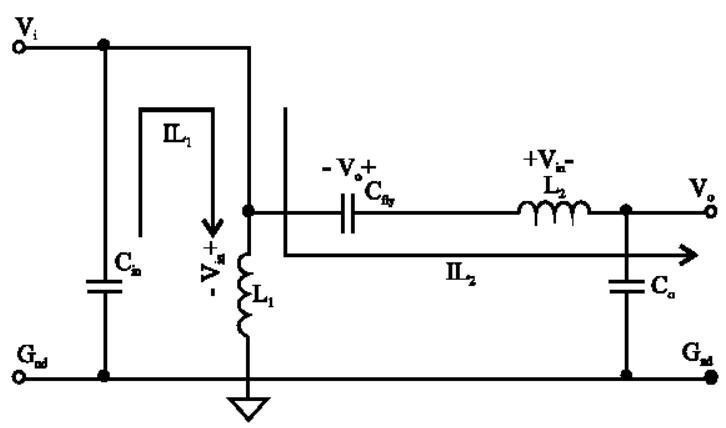

Fig. 2: Zeta converter during MOSFET ON time

voltage equivalent to $\left(\mathrm{V}_{\text {in }}+\mathrm{V}_{\mathrm{o}}\right)$ input voltage and output voltage. Inductor $L_{1}$ and $L_{2}$ get supply from the voltage source and their separate Inductive currents $I_{L 1}$ and $I_{L 2}$ are which is expanded straight upto proportion $V_{\mathrm{in}} / \mathrm{L}_{1}$ and $\mathrm{V}_{\mathrm{in}} / \mathrm{L}_{2}$ individually. Correspondingly, the switch current $I_{M 1}=I_{L 1}+I_{L 2}$ is expanded step by step by a proportion of $V_{\text {in }} / \mathrm{L}$ where, $\mathrm{L}=\mathrm{L}_{1} \cdot \mathrm{L}_{2} /\left(\mathrm{L}_{1}+\mathrm{L}_{2}\right)$. Amid this period, the releasing of capacitor $\mathrm{C}_{\mathrm{fy}}$ and charging of Capacitor $\mathrm{C}_{0}$ happens. Stage- $2\left[\mathrm{M}_{1} \mathrm{OFF}\right]$ (Fig. 2).

In this stage, the switch $M_{1}$ turns $\mathrm{OFF}$ and the $D_{1}$ Diode is in forward biased which starts to conducting. The voltage across the inductor $\mathrm{L}_{1}$ and $\mathrm{L}_{2}$ becomes equal to $-\mathrm{V}_{0}$ and inductor $\mathrm{L}_{1}$ and $\mathrm{L}_{2}$ transfer power to the Capacitor $\mathrm{C}_{\mathrm{Hy}}$ and the load simultaneously. The current of in the $L_{1}$ and $L_{2}$ decreases now gradually by a ratio of $-V_{0} / L_{1}$ and $V_{0} / L_{2}$. The current in the diode $\mathrm{I}_{\mathrm{D} 1}=\mathrm{I}_{\mathrm{L} 1}+\mathrm{I}_{\mathrm{L} 2}$ also gets decreases by a linearly by ratio of $-\mathrm{V}_{0} / \mathrm{L}$. At this period, the Voltage $(\mathrm{V})$ across switch $M_{1}$ is $V_{M}=V_{\text {in }}+V_{0}$. Figure 3 shows the inductor current waveforms of the Zeta converter for an one cycle of operation in the steady state continues mode (Krishnan and Ramkumar, 2016; Sudhakar and Ramkumar, 2016; Sownthara and Ramkumar, 2016; Ramkumar and Krishnan, 2014; Krishnan et al., 2014; Sriragavi et al., 2017; Emayavaramban and Amudha, 2006a, b) (Fig. 4).

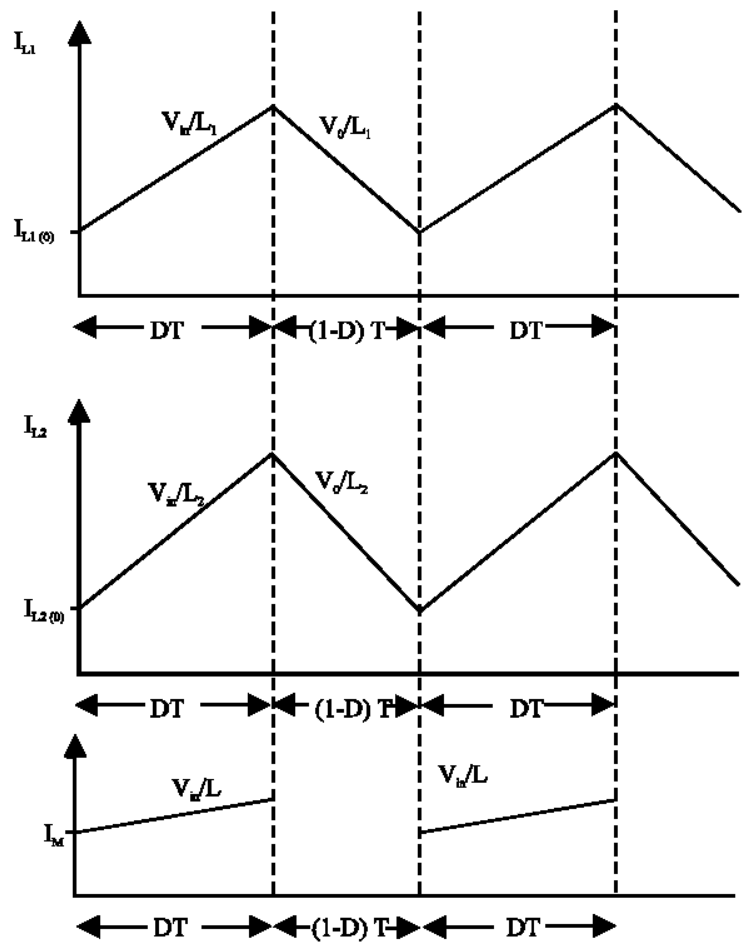

Fig. 3: Zeta converter waveforms

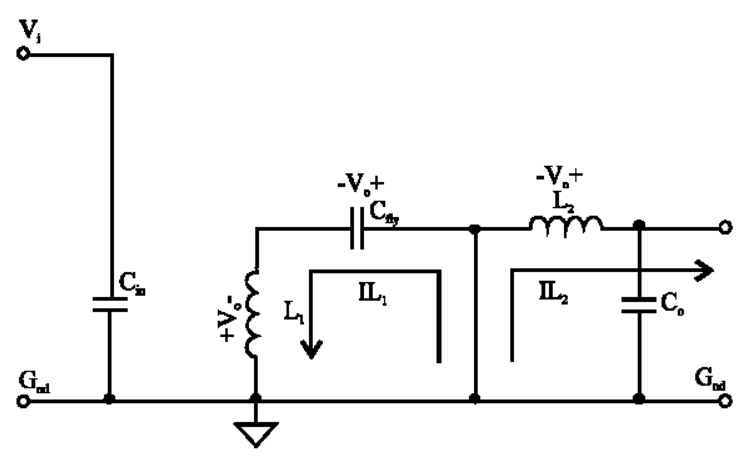

Fig. 4: Zeta converter during MOSFET off time

Design of components of Zeta converter: A Zeta converter plays out a non-altering buck-boost work. For a Zeta converter working in CCM, the duty cycle is characterized as:

$$
\begin{gathered}
D=\frac{V_{\text {OUT }}}{V_{\text {IN }}+V_{\text {OUT }}} \\
\frac{D}{1-D}=\frac{I_{\text {IN }}}{I_{\text {OUT }}}=\frac{V_{\text {OUT }}}{V_{\text {IN }}}
\end{gathered}
$$

$D_{\text {max }}$ occurs at $V_{I N(\min )}$ and $D_{\min }$ occurs at $\mathbb{N}^{(\max )}$

By Hu and Gong (2015) one of the initial phases in outlining any PWM switching controller is to choose how 
much inductor ripple current, $\Delta \mathrm{I}_{\mathrm{L}}(\mathrm{PP})$, to permit. An excessive amount of builds EMI while too little may bring about unsteady PWM operation. A dependable guideline is to relegate an incentive for $\mathrm{K}$ between 0.2 and 0.4 of the normal info current (Ramkumar et al., 2014a, b, 2016; Kavitha and Vivekanandan, 2015; Kavitha et al., 2017; Manoharan and Amudha, 2015a, b; Vijayalakshmi et al., 2014a, b, 2015; Bhavithira and Amudha, 2014; Amudha, 2014).

In a perfect, firmly coupled inductor with every inductor having a similar number of windings on a single core, the coupling force the ripple current to be part similarly between the 2 coupled inductors. In a genuine coupled inductor, the inductors don't have meet same inductance value and the ripple current won't be precisely equivalent. In any case for a desired ripple current value, the inductance required in a coupled inductor is assessed to be half of what might be required if there were 2 separate inductors as appeared in Eq. 3 (Erickson and Maksimovic, 2007):

$$
\mathrm{L} \mathrm{a}_{\min }=\mathrm{Llb}_{\min }=\frac{1}{2} \times \frac{\mathrm{V}_{\mathrm{IN}} \times \mathrm{D}}{\Delta \mathrm{I}_{\mathrm{L}(\mathrm{PP})} \times \mathrm{f}_{\mathrm{SW}(\min )}}
$$

To represent load transient, the coupled inductor's immersion current rating should be no $<1.2$ times the steady-state peak current in the high-side inductor as processed in Eq. 4 (Subramanian et al., 2017):

$$
\mathrm{I}_{\mathrm{L1a}(\mathrm{PK})}=\mathrm{I}_{\mathrm{OUT}} \times \frac{\mathrm{D}}{1-\mathrm{D}}+\frac{\Delta \mathrm{I}_{\mathrm{L}}}{2}
$$

where, $\mathrm{I}_{\mathrm{L} 1} \mathrm{~b}(\mathrm{PK})=\mathrm{I}_{\text {our }}+\Delta \mathrm{I}_{\mathrm{L}} / 2$ which is $\angle \mathrm{I}_{\mathrm{L} 1} \mathrm{a}(\mathrm{PK})$. Like a buck converter, the output of a Zeta converter has very low ripple. Equation 5 processes the part of the output ripple voltage that is expected exclusively to the capacitance value:

$$
\Delta \mathrm{V}_{\mathrm{C}_{\mathrm{OUT}}(\mathrm{PP})}=\frac{\Delta \mathrm{I}_{\mathrm{L} 1 \mathrm{~b}(\mathrm{PP})}\left[\text { at } \mathrm{V}_{\mathrm{IN}(\max )}\right]}{8 \times \mathrm{C}_{\mathrm{OUT}} \times \mathrm{f}_{\mathrm{SW}(\min )}}
$$

where, $f_{\mathrm{SW}(\mathrm{min})}$ is the minimum switching frequency. Equation 6 computes the component of the output ripple voltage that is due solely to the output capacitor's ESR (Koutroulis and Blaabjerg, 2012):

$$
\Delta \mathrm{V}_{\mathrm{ESR}_{-} \mathrm{C}_{\text {OUT }}(\mathrm{PP})}=\Delta \mathrm{I}_{\mathrm{Llb}(\mathrm{PP})}\left[\text { at } \mathrm{V}_{\mathrm{IN}(\max )}\right] \times \mathrm{ESR}_{\mathrm{CoUT}}
$$

These 2 ripple-voltage components are phase shifted and do not directly add together. The output capacitor must have a RMS rating more prominent than the capacitor RMS current registered in Eq. 7 taking after:

$$
\mathrm{I}_{\mathrm{C}_{\text {OUT (RMS) }}}=\frac{\Delta \mathrm{I}_{\mathrm{L} 16(\mathrm{PP})}\left[\mathrm{at} \mathrm{V}_{\mathrm{IN}(\max )}\right]}{\sqrt{3}}
$$

The input capacitor and the coupling capacitor source and sink the same current levels but on opposite switching cycles. Similar to a buck converter, the input capacitor and the coupling capacitor need the RMS current rating (Eq. 8) (Prabha et al., 2017):

$$
I_{\mathrm{C}_{\mathrm{HY}}(\mathrm{RMS})}=\mathrm{I}_{\mathrm{C}_{\mathrm{C}}(\mathrm{RMS})}=\mathrm{I}_{\mathrm{OUT}} \sqrt{\frac{\mathrm{V}_{\text {OUT }}}{\mathrm{V}_{\mathrm{IN}(\min )}}}
$$

Equation 9 and 10 compute the component of the output ripple voltage that is due solely to the capacitance value of the respective capacitors:

$$
\begin{gathered}
\Delta \mathrm{V}_{\mathrm{C}_{\mathrm{NI}}(\mathrm{PP})}=\frac{\mathrm{D}_{\max } \times \mathrm{I}_{\text {OUT }}}{\mathrm{C}_{\mathrm{IN}} \times \mathrm{f}_{\mathrm{SW}(\min )}} \\
\Delta \mathrm{V}_{\mathrm{C}_{\mathrm{C}}(\mathrm{PP})}=\frac{\mathrm{D}_{\max } \times \mathrm{I}_{\mathrm{OUT}}}{\mathrm{C}_{\mathrm{C}} \times \mathrm{f}_{\mathrm{SW}(\min )}}
\end{gathered}
$$

Equation 11 and 12 compute the component of the output ripple voltage that is due solely to the ESR value of the respective capacitors:

$$
\begin{aligned}
& \Delta \mathrm{V}_{\mathrm{ESR}_{-} \mathrm{C}_{\mathrm{NI}}(\mathrm{PP})}=\left(\mathrm{I}_{\mathrm{IN}(\max )}+\mathrm{I}_{\mathrm{OUT}}\right) \times \\
& \mathrm{ESR}_{\mathrm{C}_{\mathrm{IN}}}=\frac{\mathrm{I}_{\mathrm{OUT}}}{1-\mathrm{D}_{\max }} \times \mathrm{ESR}_{\mathrm{C}_{\mathrm{NI}}} \\
& \Delta \mathrm{V}_{\mathrm{ESR}_{-} \mathrm{C}_{\mathrm{C}}(\mathrm{PP})}=\left(\mathrm{I}_{\mathrm{IN}(\max )}+\mathrm{I}_{\mathrm{OUT}}\right) \times \\
& \mathrm{ESR}_{\mathrm{C}_{\mathrm{C}}}=\frac{\mathrm{I}_{\mathrm{OUT}}}{1-\mathrm{D}_{\max }} \times \mathrm{ESR}_{\mathrm{C}_{\mathrm{C}}}
\end{aligned}
$$

Again, the 2 ripple-voltage components are phase-shifted and do not directly add together and for low-ESR capacitors, the ESR component can again be ignored. A typical ripple value is $<0.05$ times the input voltage for the input capacitor and $<0.02$ times the output voltage for the coupling capacitor (Balachander and Ponnusamy, 2012a, b; Balachander et al., 2012a, b; Balachander, 2012; Kuppusamy and Balachander, 2012; Ramkumar et al., 2018; Balachander and Amudha, 2017a, b; Sriragavi et al., 2017; Amudha et al., 2017a, b, 2012; Motapon et al., 2014; Kochcha and Sujitjorn, 2010; Singh and Chaturvedi, 2008). 


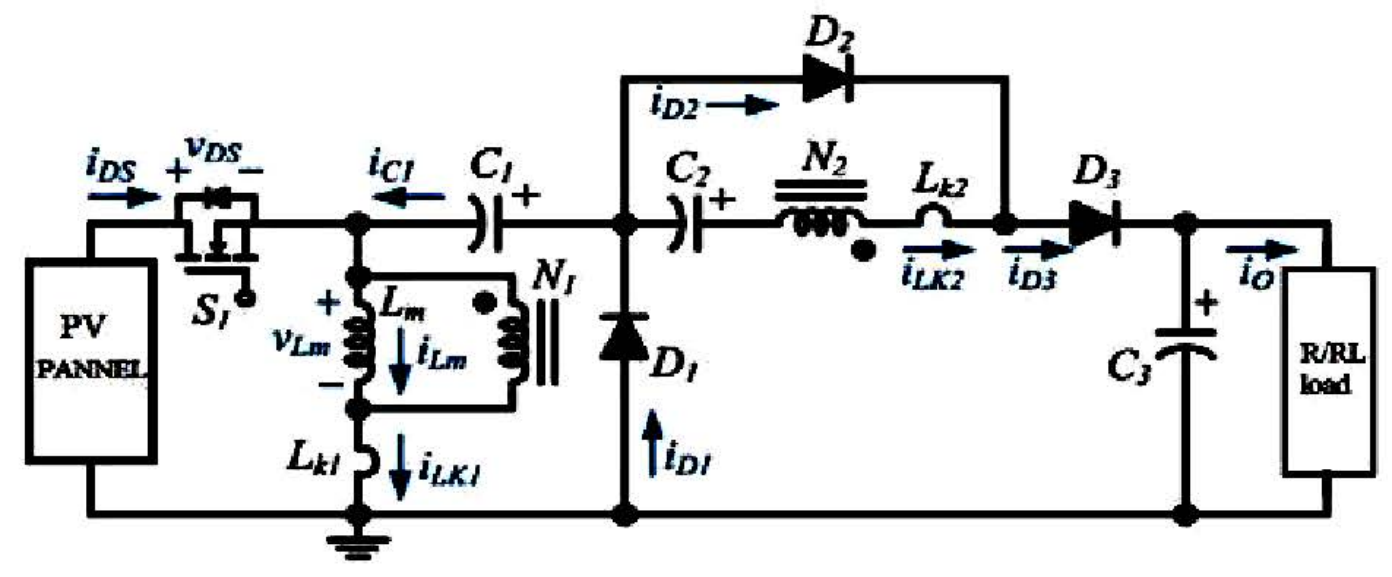

Fig. 5: Proposed Zeta converter

Converters operating principles of the proposed: Figure 3 demonstrates the circuit design of the proposed converter which comprises of two dynamic switch $\mathrm{S}_{1}$, one coupled inductor, 3 Diodes $\mathrm{D}_{1} \sim \mathrm{D}_{3}$ and 3 Capacitor $\mathrm{C}_{1} \sim \mathrm{C}_{3}$. The coupled inductor is displayed as a charging inductor $\mathrm{L}$ essential spillage inductor $\mathrm{L}_{\mathrm{k} 1}$, secondary leakage inductor $\mathrm{L}_{\mathrm{k} 2}$ (Fig. 5).

All parts are perfect. The On-state resistance RDS (ON) of the dynamic switches, the forward voltage drop of the diodes and the comparable arrangement resistance (ESR) of the coupled-inductor and output capacitors are overlooked the turns proportion $n$ of the coupled inductor $T_{1}$ winding is equivalent to $\mathrm{N}_{2} \mathrm{~N}_{1}$ Figure 4 demonstrates some run of the mill waveforms amid one exchanging period in Constant Conduction Mode (CCM) operation. The working standard and the 5 working modes are portrayed as takes after (Vijayalakshmi et al., 2014a, b; Amudha and Rajan, 2012; Amudha and Christopher, 2012; Christopher and Christopher, 2012; Amudha and Rajan, 2013, 2014; Balachander, 2017; Balachander and Amudha, 2017a, b; Sangeetha and Balachander, 2016; Balachander and Vijayakumar, 2013a-d).

\section{CCM operation}

Mode $1\left[\mathbf{t}_{0}, \mathbf{t}_{\mathbf{l}}\right]$ : In this interval the Capacitor $\mathrm{C}_{2}$ get vitality energy from the secondary leakage inductor $\mathrm{L}_{\mathrm{k} 2}$. The current way is appeared in Fig. 6a; Switch $\mathrm{S}_{1}$ and Diodes $\mathrm{D}_{2}$ are leading. The source Voltage $\mathrm{V}_{\text {in }}$ is connected on charging inductor $\mathrm{L}_{\mathrm{m}}$ and essential spillage inductor $\mathrm{L}_{\mathrm{k} 1}$, the current $i_{L m}$ is diminished in the meantime, Lm additionally discharges its vitality to the optional twisting and also charges the Capacitor $\mathrm{C}_{2}$ alongside the lessening in vitality equation:

$$
\begin{aligned}
& \mathrm{i}_{\mathrm{m}}(\mathrm{t})=\mathrm{i}_{\mathrm{DS}}(\mathrm{t})=\mathrm{i}_{\mathrm{Lk} 1}(\mathrm{t}) \\
& \frac{\mathrm{di}_{\mathrm{Lm}}(\mathrm{t})}{\mathrm{dt}}=\frac{\mathrm{V}_{\mathrm{Lm}}}{\mathrm{Lm}} \\
& \frac{\mathrm{di}_{L k 1}(\mathrm{t})}{\mathrm{dt}}=\frac{\mathrm{V}_{\mathrm{in}}-\mathrm{V}_{\mathrm{Lm}}}{\mathrm{L}_{\mathrm{k} 1}} \\
& \mathrm{i}_{\mathrm{Lk} 2}(\mathrm{t})=\mathrm{i}_{\mathrm{Lm}}(\mathrm{t})-\mathrm{i}_{\mathrm{Lk} 1}(\mathrm{t})
\end{aligned}
$$

Mode $2\left[\mathbf{t}_{\mathbf{1}}, \mathbf{t}_{2}\right]$ : During this interval, source vitality vinis associated in arrangement with $\mathrm{C}_{1}, \mathrm{C}_{2}$, optional winding $\mathrm{N}_{2}$ and $\mathrm{L}_{\mathrm{k} 2}$ to charge output capacitor $\mathrm{C}_{3}$ and load $\mathrm{R}$ in the meantime, polarizing inductor $\mathrm{L}_{\mathrm{m}}$ additionally gets vitality from $V_{\text {in }}$. The way of current current is appeared in Fig. 6b as outlined, Switch $S_{1}$ remains on and just Diode $D_{3}$ is in conduction. The $\mathrm{i}_{\mathrm{Lm}}, \mathrm{i}_{\mathrm{Lk} 1}$ and $\mathrm{i}_{\mathrm{D} 3}$ have been expanding in light of the fact that the $\mathrm{V}_{\text {in }}$ is intersection $\mathrm{L}_{\mathrm{k} 1}, \mathrm{~L}_{\mathrm{m}}$ and essential winding $\mathrm{N}_{1} ; \mathrm{L}_{\mathrm{m}}$ and $\mathrm{L}_{\mathrm{k} 1}$ are putting away vitality from $V_{\text {in }}$ and in addition, $V_{\text {in }}$ is additionally in arrangement with $\mathrm{N}_{2}$ of coupled inductor $\mathrm{T}_{1}$ and Capacitors $C_{1}$ and $C_{2}$ have been releasing their vitality to Capacitor $\mathrm{C}_{3}$ and load $\mathrm{R}$ that prompts to increments in $\mathrm{i}_{\mathrm{Lm}}$, $i_{L k 1}, i_{D S}$ and $i_{D 3}$. This mode closes at $t=t_{2}$ at which turn $\mathrm{S}_{1}$ is off (Shaik and Babu, 2012; Martins et al., 1996; Tse, 2003; Singh et al., 2008; Martins and De Abreu, 1993; Garcia et al., 2003; Lascu et al., 2005; Anonymous, 2007):

$$
\begin{aligned}
& \mathrm{i}_{\mathrm{Lm}}(\mathrm{t})=\mathrm{i}_{\mathrm{Lk} 1}(\mathrm{t})-\mathrm{ni}_{\mathrm{Lk} 2}(\mathrm{t}) \\
& \frac{\mathrm{di}_{\mathrm{Lm}}(\mathrm{t})}{\mathrm{dt}}=\frac{\mathrm{V}_{\mathrm{in}}}{\mathrm{Lm}} \\
& \mathrm{i}_{\mathrm{m}}(\mathrm{t})=\mathrm{i}_{\mathrm{LS}}(\mathrm{t})=\mathrm{i}_{\mathrm{Lm}}(\mathrm{t})+(1+\mathrm{n}) \mathrm{i}_{\mathrm{Lk} 2}(\mathrm{t}) \\
& \frac{\mathrm{di}_{\mathrm{Lk} 2}(\mathrm{t})}{\mathrm{dt}}=\frac{\mathrm{di}_{\mathrm{D} 3(\mathrm{t})}}{\mathrm{dt}}=\frac{(1+\mathrm{n}) \mathrm{V}_{\mathrm{in}}+\mathrm{V}_{\mathrm{C} 1}+\mathrm{V}_{\mathrm{C} 2}}{\mathrm{Lk} 2}
\end{aligned}
$$

Mode $3\left[\mathbf{t}_{2}, \mathbf{t}_{\mathbf{3}}\right.$ ]: During this move interval, $\mathrm{C}_{3}$ is being charged from auxiliary spillage inductor $L_{k 2}$ when turn $S_{1}$ 

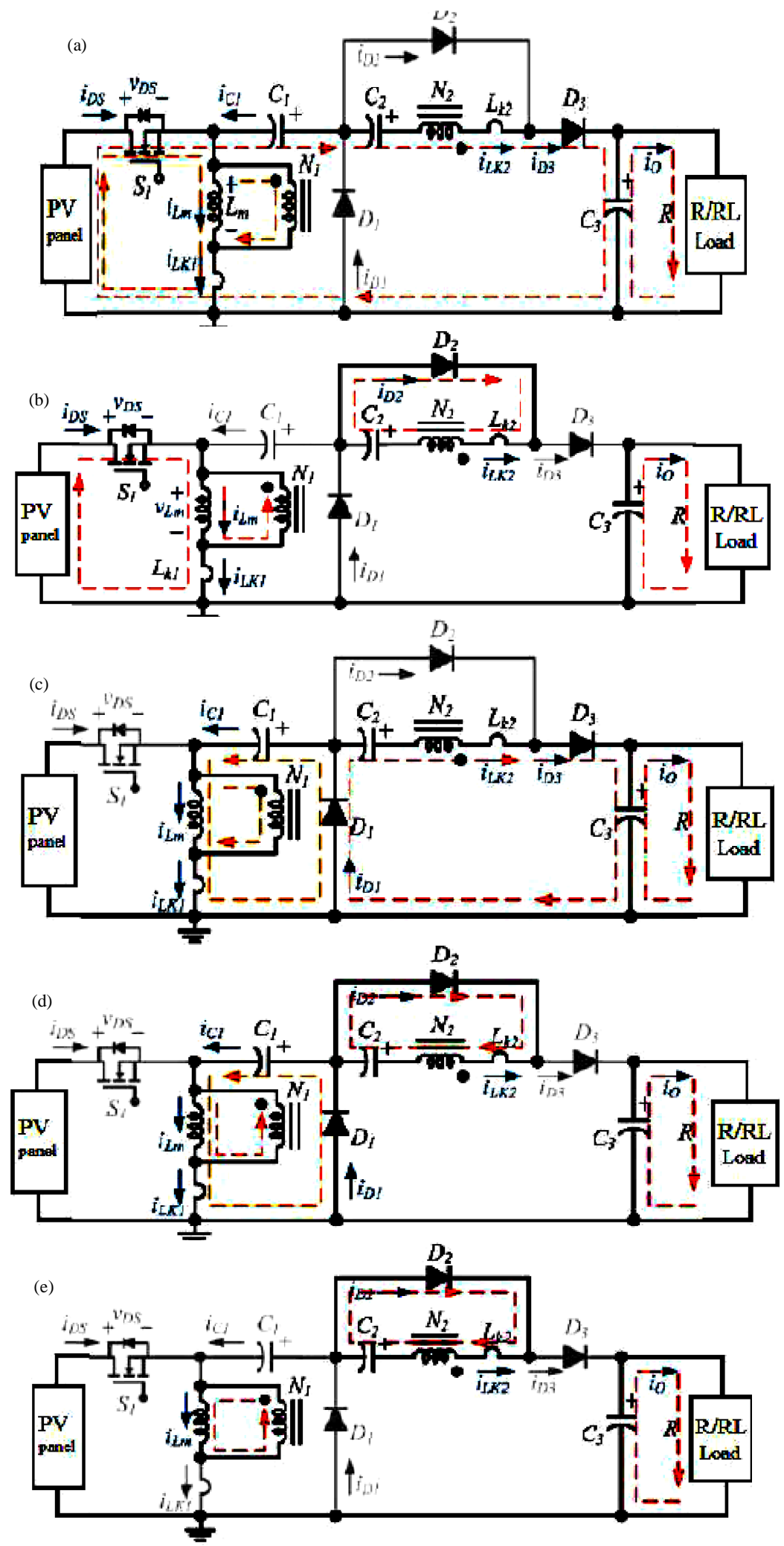

Fig. 6: During CCM operation, current flowing path in 5 modes operation: a) Mode 1; b) Mode 2; c) Mode 3; d) Mode 4 and e) Mode 5 
is off. The present current way is appeared in Fig. 6 and the Diodes $D_{1}$ and $D_{3}$ are directing. The vitality put away in spillage inductor $L_{k 1}$ is coursing through Diode $D_{1}$ and the Capacitor $C_{1}$ is charged in a split second when $S_{1}$ off. Additionally, the $\mathrm{L}_{\mathrm{k} 2}$ keeps an indistinguishable current bearing from in the past mode. The auxiliary spillage inductor current $i_{\mathrm{LK} 2}$ is being declined by $i_{\mathrm{Lm} / \mathrm{r}}$. Current $i_{\mathrm{Lk} 1}$ when the expanding $i_{\mathrm{Lk} 1}$ approaches the diminishing $i_{\mathrm{Lm}}$ this mode closes at $t=t_{1}$. Once when the current $i_{\text {Lk2 } 2}$ drops to zero, this mode ends at $t=t_{3}$ :

$$
\begin{aligned}
& i_{\text {in }}(t)=i_{D S}(t)=i_{L k 1}(t) \\
& \frac{d i_{L m}(t)}{d t}=\frac{V_{L m}}{L m} \\
& \frac{d i_{L k 1}(t)}{d t}=\frac{V_{i n}-V_{L m}}{L_{k 1}} \\
& i_{L k 2}(t)=i_{L m}(t)-i_{L k 1}(t)
\end{aligned}
$$

Mode $4\left[\mathbf{t}_{3}, \mathbf{t}_{4}\right]$ : In this move interim, the vitality put away in charging inductor $\mathrm{Lm}$ is discharged all the while to $\mathrm{C}_{1}$ and $\mathrm{C}_{2}$. The present stream way is appeared in Fig. $6 \mathrm{~d}$ what's more, the Diodes $D_{1}$ and $D_{2}$ are leading. As spillage vitality still courses through Diode $\mathrm{D}_{1}$ and keeps on charging Capacitor $C_{1}$, currents $i_{1 k 1}$ and $i_{D 1}$ are relentlessly being diminished through $T_{1}$ and $D_{2}$, the $L_{m}$ is conveying its vitality for charging Capacitor $\mathrm{C}_{2}$. The vitality put away in Capacitors $\mathrm{C}_{3}$ is released always to the heap $\mathrm{R}$. The voltage crosswise over $S_{1}$ is the same as in the earlier mode. Current $i_{D 2}$ is expanding, yet, $i$ uand $i$ are diminishing, yet. This mode closes when current $i_{\text {Lk1 }}$ gets to be distinctly zero at $\mathrm{t}=\mathrm{t}_{4}$ (Singh et al., 2015; Chen et al., 2013; Vuthchhay and Bunlaksananusorn, 2008; Dhali et al., 2012; Wei and Batarseh, 1998).

\section{RESULTS AND DISCUSSION}

Conventional open loop Zeta converter with RL load: The significance of recreation is evident for the preparatory outline design of any system. System conduct and execution can be anticipated with the assistance of the reproduction. To confirm and examine the outline and execution of the preparatory stage, a re-enactment investigation of Zeta converter in open loop is perform med for info DC voltage of $15 \mathrm{~V}$ at $50 \mathrm{~Hz}$ and output DC Voltage of $8.5 \mathrm{~V}$ and $14 \mathrm{~W}$ output control rating with an exchanging recurrence of $10 \mathrm{kHz}$ with $\mathrm{RL}$ load (Ramkumar, 2017).

Power circuit of Zeta converter with open loop is shown in Fig. 5. AC input voltage is shown in Fig. 6. Switching pulse and Vds for MOSFET is shown in Fig. 7. Output voltage and output current and output power are

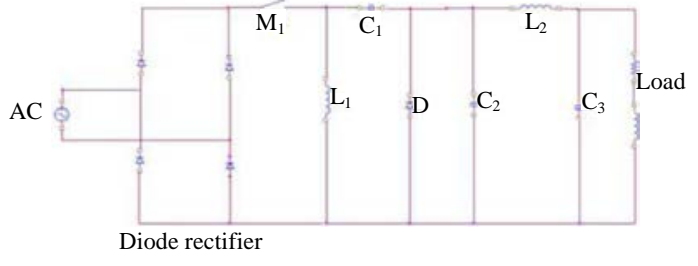

Fig. 7: Open loop Zeta converter

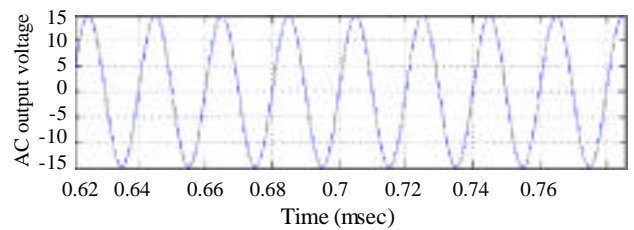

Fig. 8: AC input voltage
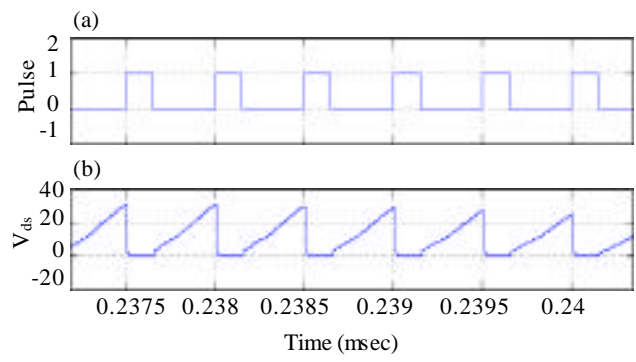

Fig. 9: Switching pulse and $V_{d s}$ for $M_{1}$

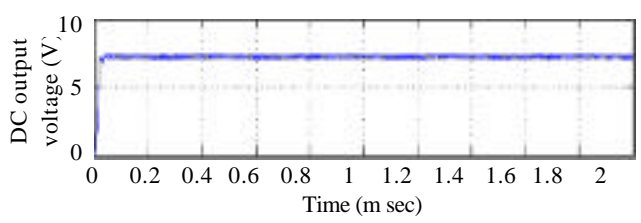

Fig. 10: Output voltage

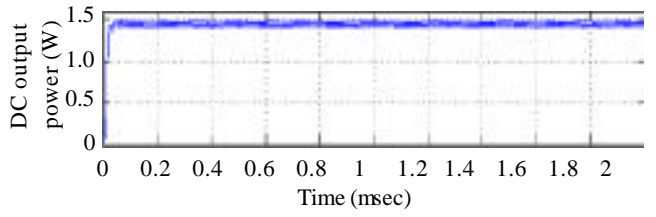

Fig. 11: Output power

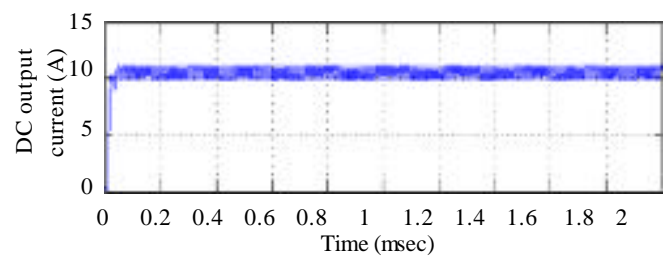

Fig. 12: Output current

shown in Fig. 8-10, respectively, power factor for open loop Zeta converter is shown in Fig. 11. Total harmonic distortion is shown in Fig. 12 and 13. For conventional circuit THD value is very high (Sivakumar etal., 2017). 


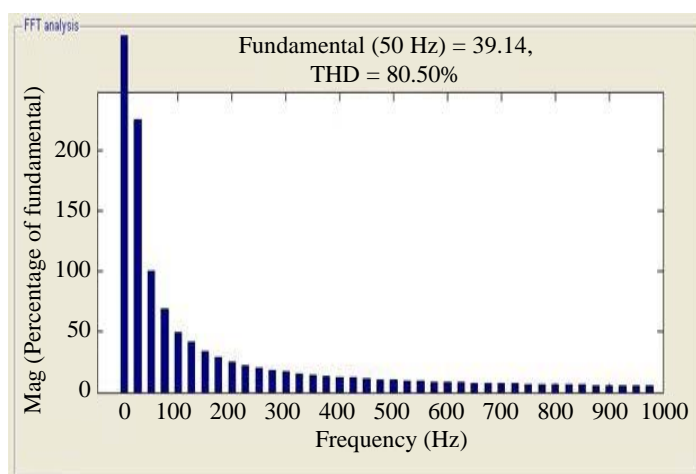

Fig. 13: FFT analysis for open loop Zeta converter

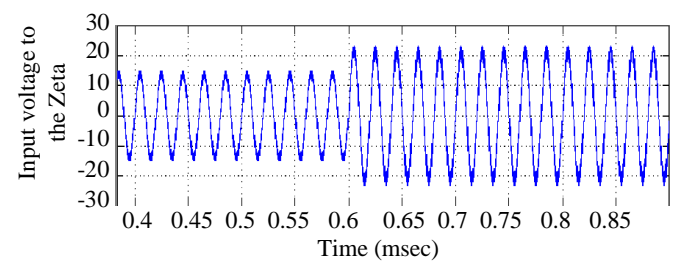

Fig. 14: Input voltage to the Zeta converter

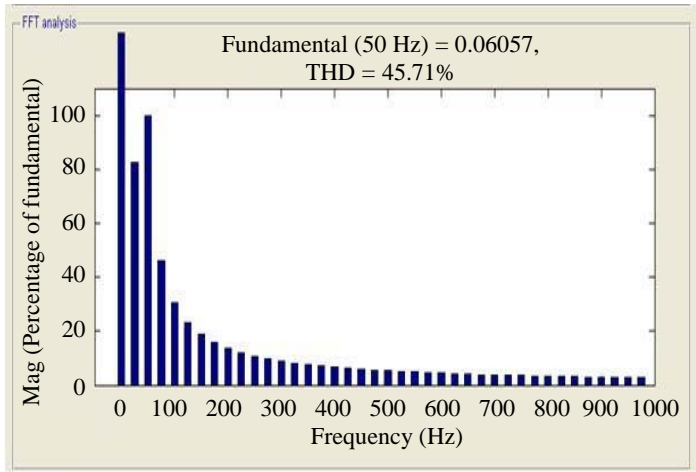

Fig. 15: FFT analysis for open loop Zeta converter with disturbance

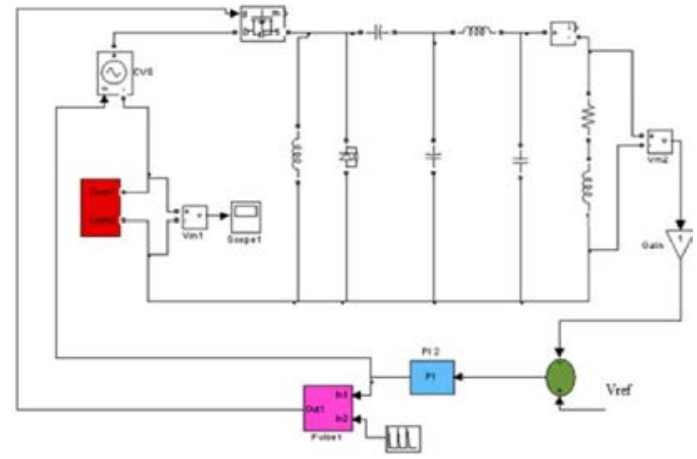

Fig. 16: Proposed closed loop Zeta converter with RL load

Conventional open loop Zeta converter with disturbance in the input side: In the circuit of conventional open loop

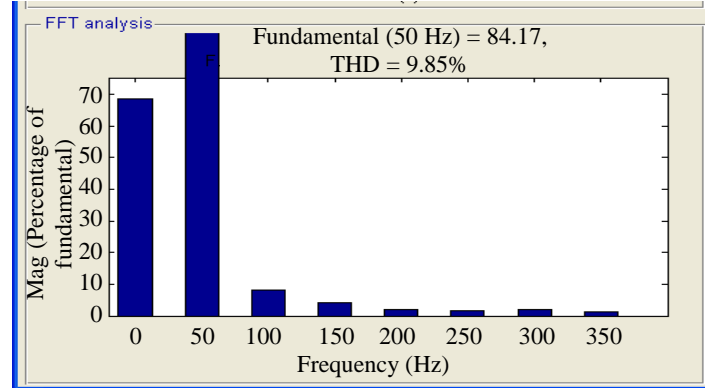

Fig 17: FFT analysis for closed loop Zeta converter

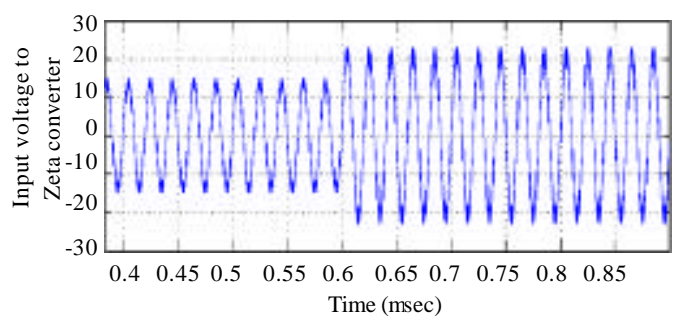

Fig. 18: Input voltages

Zeta converter, a step disturbance is given in the input side. Input voltage, output voltage, output current and output voltage of the circuit is shown in Fig. 14-17, respectively. Total harmonic distortion is shown in Fig. 18.

Proposed closed loop Zeta converter with RL load: The closed loop Zeta converter for PFC with RL load. It uses a very simple control feedback which only requires output voltage sensing (Subramanian et al., 2017).

At the input $\mathrm{AC}$ side a bridge rectifier is used for a $\mathrm{PFC}$ using an capacitor and inductor combination. A small value of $V_{0}$, compared to the reference value and resulting value, passes through the Proportional Integral (PI) controller generates the PWM output and which has been used for switching the MOSFET (M1). This kind of inherent PFC characteristics with constant duty ratio and switching frequency, offering an attractive solution for lower power applications (Erickson and Maksimovic, 2007).

The output voltage direction is given by the input circle as appeared in Fig. 19 where the output detected Voltage $V_{0}$ is contrasted and a reference $V_{\text {ref }}$ current and the blunder is enhanced in a corresponding essential (PI) controller which is contrasted and a saw-tooth slope $V_{s}$ in this manner giving the beat to power switch. Subsequently, this circuit is controlled by the distinction in the on time interim and the steady exchanging recurrence $\mathrm{f}_{\mathrm{s}}$ (Yuvaraj et al., 2017; Prabha et al., 2017). 


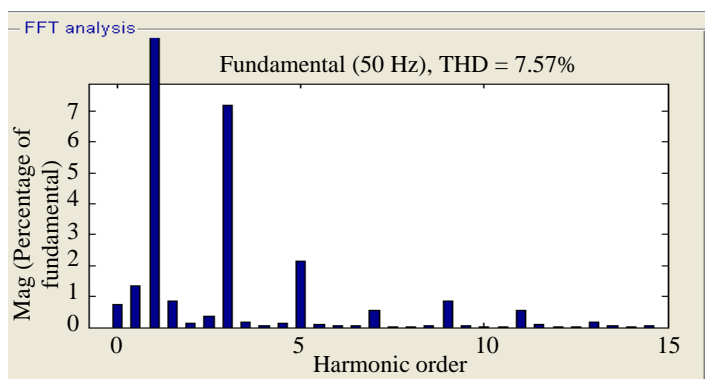

Fig. 19: FFT Analysis for closed loop Zeta converter with disturbance

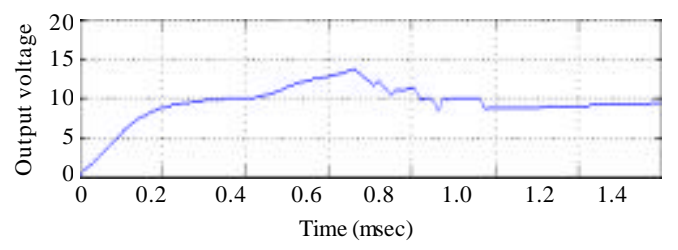

Fig. 20: Output current

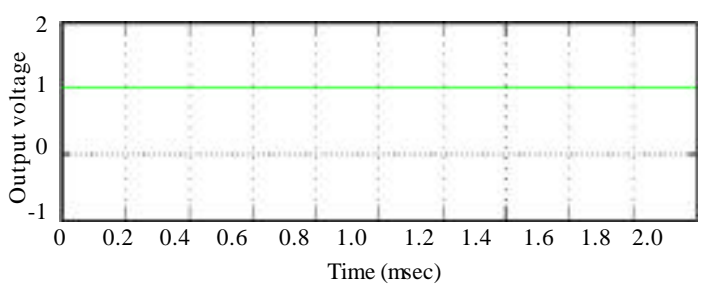

Fig. 21: Power factor proposed references ciruit

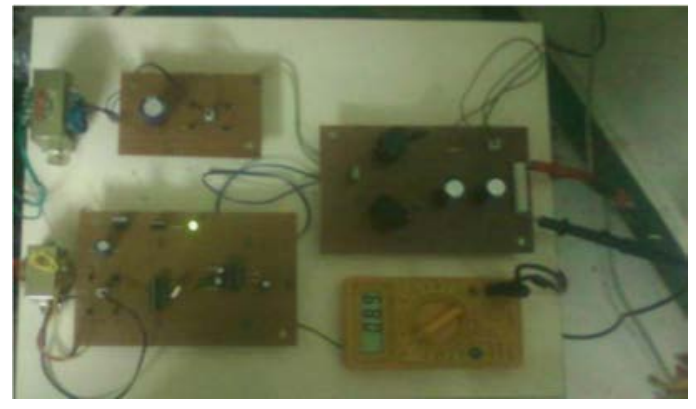

Fig. 22: Hardware setup

Input voltage, output voltage and output current are appeared in Fig. 20-22 individually. Control figure for closed loop circle Zeta converter is appeared in Fig. 22 (Tao et al., 2008)

Proposed closed loop Zeta converter with disturbance in the input side: In the circuit of closed loop Zeta converter, a step disturbance is given in the input side. Input voltage, output voltage and output current for the circuit is shown in Fig. 20-22. Total harmonic
Table 1: Closed loop Zeta converter

\begin{tabular}{lccc}
\hline Input voltage & Output voltage & Output power & Efficiency (\%) \\
\hline 12 & 4.30 & 3.80 & 92.0 \\
13 & 7.60 & 11.40 & 93.1 \\
14 & 8.10 & 13.13 & 94.0 \\
15 & 8.45 & 14.29 & 94.5 \\
\hline
\end{tabular}

Table 2: Open loop Zeta converter

\begin{tabular}{lccc}
\hline Input voltage & Output voltage & Output power & Efficiency (\%) \\
\hline 12 & 6.50 & 8.59 & 91.0 \\
13 & 7.10 & 10.28 & 92.3 \\
14 & 7.78 & 12.10 & 92.6 \\
15 & 8.50 & 14.08 & 93.1 \\
\hline
\end{tabular}

distortion is shown in Fig. 17 and 19 (Kochcha and Sujitjorn, 2010; Singh and Chaturvedi, 2008; Shaik and Babu, 2012; Martins et al., 1996; Tse, 2003; Singh et al., 2008; Martins and De Abreu, 1993; Garcia et al., 2003; Lascu et al., 2005; Anonymous, 2007; Singh et al., 2015; Chen et al., 2013; Vuthchhay and Bunlaksananusorn, 2008; Dhali et al., 2012; Wei and Batarseh, 1998).

Experimental results: Hardware results are shown in the following section for proposed method and an experimental prototype model of the PWM Zeta converter has been constructed. The hardware setup with detailed specifications is shown in Fig. 23. IR2110 is used as the driver circuit. $\mathrm{PICl} 6 \mathrm{~F} 84 \mathrm{~A}$ is used as the processor. A $\mathrm{Pi}$-filter is added to avoid control error caused by the switch noise.

Performance tabulation: Table 1 and 2 is discuss in the performance tabulation.

\section{CONCULSION}

The performance of Zeta converter is compared by comparing converter in both open loop and in closed loop. Zeta converter in closed loop has low THD value and power factor near to unity than open loop system. This study clarifies the pulse width regulated Zeta converter. In this study, design and simulation of Zeta converter in open loop and closed loop are taken for $9.2 \mathrm{~V}, 15 \mathrm{~W}$ output. Both the circuits are recreated with RL load. The closed loop Zeta converter has an efficiency of $96.5 \%$. The THD of the closed loop Zeta converter is good comparing to open loop. The power factor level is very near to unity. The closed loop Zeta converter proposed circuit has low THD. It permits remedy of current working in discontinuous mode and in this way it is more sufficient for the application with high power gain. The efficiency of Zeta in open loop and closed loop is discussed in this study, respectively. Thus, Zeta converter in closed loop with ZVZCS gives better performance comparing it with to previous methods. 


\section{REFERENCES}

Amudha, A. and A.R. Christopher, 2012. GENCOS strategies for selling power and reserve using hybrid algorithms of LR, GD and ANN. Wulfenia J., 19: 99-118.

Amudha, A. and C.A. Rajan, 2012. GENCOS strategies for selling power and reserve using particle swarm optimization. Eur. J. Sci. Res., 85: 408-417.

Amudha, A. and C.C.A. Rajan, 2013. Generator scheduling under competitive environment using memory management algorithm. Alexandria Eng. J., 52: 337-346.

Amudha, A. and C.C.A. Rajan, 2014. Integrating gradient search, logistic regression and artificial neural network for profit based unit commitment. Intl. J. Comput. Intell. Syst., 7: 90-104.

Amudha, A., 2014. Optimal placement of unified power flow controller in the transmission line using SLF algorithm. Appl. Mech. Mater., 573: 352-355.

Amudha, A., A. Rajan and C. Christober, 2012. Online application of profit based unit commitment using Hybrid algorithms of memory management Algorithm. Intl. J. Adv. Mater. Res., 403: 3965-3972.

Amudha, A., K. Balachander and M.S. Ramkumar, 2017a. Power conservation and control in base transceiver station towers using SCADA. Int. J. Scient. Res. Rev., 6: 149-156.

Amudha, A., M.S. Ramkumar and M.S. Krishnan, $2017 \mathrm{~b}$. Perturb and observe based photovoltaic power generation system for off-grid using SEPIC converter. Int. J. Pure Applied Math., 114: 619-628.

Anonymous, 2007. Zeta converter basics based on Sipex's SP6125/6/7 controllers. Sipex Corporation Fremont, California, sUSA.

Balachander, K. and A. Amudha, 2017b. Design and hardware implementation of interleaved boost converter using sliding mode approach. Int. J. Electron. Eng. Res., 9: 745-750.

Balachander, K. and A. Amudha, 2017a. PLC based control of fuel oil pump houses in thermal power station. Int. J. Scient. Res. Rev., 6: 6-14.

Balachander, K. and P. Vijayakumar, 2013b. Modeling, simulation and optimization of hybrid renewable energy systems in technical, environmental and economical aspects: Case study Pichanur village, Coimbatore, India. Int. J. Applied Environ. Sci., 8: 2035-2042.

Balachander, K. and P. Vijayakumar, 2013c. Modeling, simulation and optimization of hybrid renewable power system for daily load demand of metropolitan cities in India. Am. J. Eng. Res., 2: 174-184.
Balachander, K. and P. Vijayakumar, 2013a. Optimization of cost of energy of real time renewable energy system feeding commercial load, case study: A textile showroom in Coimbatore, India. Life Sci. J., 10: 839-847.

Balachander, K. and P. Vijayakumar, 2013. Renewable energy system optimization of two different locations. CiiT Int. J. Autom. Autonomous Syst., 5: 47-50.

Balachander, K. and V. Ponnusamy, 2012a. Economic analysis, modeling and simulation of photovoltaic fuel cell hybrid renewable electric system for smart grid distributed generation system. Int. J. Mech. Eng. Technol., 3: 179-186.

Balachander, K. and V. Ponnusamy, 2012b. Optimization, simulation and modeling of renewable electric energy system with HOMER. Int. J. Applied Eng. Res., 7: 247-256.

Balachander, K., 2012. A review of modeling and simulation of PV module. Elixir Electr. Eng., 42: 6798-6802.

Balachander, K., 2017. Design and hardware implementation of speed control of induction motor using Z-source inverter. Int. J. Electron. Eng. Res., 9: 931-937.

Balachander, K., S. Kuppusamy and P. Vijayakumar, 2012 b. Comparative study of hybrid photovoltaic-fuel cell system/hybrid wind-fuel cell system for smart grid distributed generation system. Proceedings of the International Conference on Emerging Trends in Science, Engineering and Technology (INCOSET), December 13-14, 2012, IEEE, Tiruchirappalli, India, ISBN:978-1-4673-5141-6, pp: 462-466.

Balachander, K., S. Kuppusamy and V. Ponnusamy, 2012a. MA modeling and simulation of VSDFIG and PMSG wind turbine system. Int. J. Electr. Eng., 5: 111-118.

Bhavithira, V. and A. Amudha, 2014. Enhancement of available transfer capability using facts controller. Appl. Mech. Mater., 573: 340-345.

Chen, K.M., T.J. Liang, S.M. Chen and K.H. Chen, 2013. Design and implementation of a interleaved single-phase power factor correction Zeta converter. Proceedings of the 2013 IEEE 10th International Conference on Power Electronics and Drive Systems (PEDS), April 22-25, 2013, IEEE, Kitakyushu, Japan, ISBN:978-1-4673-1790-0, pp: 171-174.

Christopher, A. and A.R. Christopher, 2012. GENCOS strategies for selling power with effect of reserve using memory management algorithm. Arch. Des Sci., 65: 349-358.

Dhali, S., P.N. Rao, P. Mande and K.V. Rao, 2012. PWM-based sliding mode controller for DC-DC boost converter. Int. J. Eng. Res. Appl., 2: 618-623. 
Emayavaramban, G. and A. Amudha, 2006. Identifying hand gestures using sEMG for human machine interaction. ARPN. J. Eng. Appl. Sci., 11: 12777-12785.

Emayavaramban, G. and A. Amudha, 2016a. sEMG based classification of hand gestures using artificial neural network. Indian J. Sci. Technol., 9: 1-10.

Emayavaramban. G. and A. Amudha, 2016b. Recognition of sEMG for prosthetic control using static and dynamic neural networks. Intl. J. Control Theor. Appl., 2: 155-165.

Erickson, R.W. and D. Maksimovic, 2007. Fundamentals of Power Electronics. 2nd Edn., Springer, Berlin, Germany, ISBN:978-1-4757-0559-1, Pages: 871.

Garcia, O., J.A. Cobos, R. Prieto, P. Alou and J. Uceda, 2003. Single phase power factor correction: A survey. IEEE. Trans. Power Electron., 18: 749-755.

Govindaraju, K., V. Bhavithira, D. Kavitha, S. Kuppusamy and $\mathrm{K}$. Balachander, 2017. Improvement of voltage profile and loss minimization in IEEE 14 bus system using facts devices. Int. J. Control Theory Applic., 10: 213-224.

$\mathrm{Hu}, \mathrm{X}$. and C. Gong, 2015. A high gain input-parallel output-series DC/DC converter with dual coupled inductors. IEEE. Trans. Power Electron., 30: 1306-1317.

Jeyakrishna, K.R., A. Amudha, K. Balachander and M.S. Ramkumar, 2017. Electric vehicle battery charging station using dual converter control. Int. J. Control Theory Applic., 10: 195-203.

Kavitha, D. and C. Vivekanandan, 2015. An adjustable speed PFC Buck-boost converter fed sensorless BLDC motor. Intl. J. Appl. Eng. Res., 10: 17749-17754.

Kavitha, D., A. Amudha and S. Divya-priya, 2017. Design of a controller for regenerative braking using BLDC motor applicable for electric vehicle. Intl. J. Electron. Electr. Comput. Syst., 6: 245-252.

Kochcha, P. and S. Sujitjorn, 2010. Isolated zeta converter: Principle of operation and design in continuous conduction mode. WSEAS. Trans. Circuits Syst., 9: 483-492.

Koutroulis, E. and F. Blaabjerg, 2012. Methodology for the optimal design of transformerless grid-connected PV inverters. IET. Power Electron., 5: 1491-1499.

Krishnan, M.S. and M.S. Ramkumar, 2016. Power management of hybrid renewable energy system by frequency deviation control. Int. J. Innov. Res. Sci. Eng. Technol., 3: 763-769.

Krishnan, M.S., M.S. Ramkumar and A. Amudha, 2017. Frequency deviation control in hybrid renewable energy system using FC-UC. Int. J. Control Theory Applic., 10: 333-344.

Krishnan, M.S., S.K. Dhevi and M.S. Ramkumar, 2014. Power quality analysis in hybrid energy generation system. Int. J. Adv. Res. Comput. Sci. Manage. Stud., 2: $188-193$.
Kumar, M.S.R., A. Amudha and R. Rajeev, 2016. Optimization for a novel single switch resonant power converter using GA to improve mppt efficiency of PV applications. Int. J. Applied Eng. Res., 11: 6485-6488.

Kuppusamy, S. and K. Balachander, 2012. Embedded based capacitance fuel level sensor. Elixir Electr. Eng., 43: $6751-6754$.

Lascu, D., V. Popescu, D. Negoipescu, A. Popovici and M. Lascu et al., 2005. Modelling, analysis, simulation and experimental results regarding a new boost converter topology. Proceedings of the 2005 WSEAS International Conference on Dynamical Systems and Control, November 2-4, 2005, WSEAS Press, Venice, Italy, pp: 433-438.

Latha, M.R., S. Kuppusamy, A. Amudha, K. Balachander and M.S. Ramkumar, 2017. An efficient single stage converter based PV-DVR for improving voltage quality. Int. J. Control Theory Applic., 10: 177-193.

Manoharan, D. and D.A. Amudha, 2015b. A novel optimization of stresses acting and failure rates with power transformer. Intl. J. Appl. Eng. Res., 10: 6233-6240.

Manoharan, D. and D.A. Amudha, 2015a. Condition monitoring and life extension of EHV transformer. Intl. J. Appl. Eng. Res., 10: 3277-3280.

Martins, D.C. and G.N. De Abreu, 1993. Application of the ZETA converter in switched-mode power supplies. Proceedings of the International Conference on Record of the Power Conversion Conference-Yokohama, April 19-21, 1993, IEEE, Yokohama, Japan, pp: 147-152.

Martins, D.C., D.S.F. Campos and I. Barbi, 1996. Zeta converter with high power factor operating in continuous conduction mode. Proceedings of the 1996 IEEE 22nd International Conference on Industrial Electronics, Control and Instrumentation (IECON) Vol. 3, August 9, 1996, IEEE, Taipei, Taiwan, pp: 1802-1807.

Motapon, S.N., L.A. Dessaint and K. Al-Haddad, 2014. A comparative study of energy management schemes for a fuel-cell hybrid emergency power system of more-electric aircraft. IEEE. Trans. Ind. Electron., 61: 1320-1334.

Prabha, V.C., A. Amudha, K. Balachander and M.S. Ramkumar, 2017. MPPT algorithm for grid integration of variable speed wind energy conversion system. Int. J. Control Theory Applic., 10: 237-246.

Ramkumar, M.S. and M.S. Krishnan, 2014. Power management of a hybrid solar-wind energy system. Int. J. Eng. Res. Technol., 3: 1988-1992.

Ramkumar, M.S., 2017. Unmanned automated railway level crossing system using zigbee. Int. J. Electron. Eng. Res., 9: 1361-1371. 
Ramkumar, M.S., A. Amudha, M.S. Krishan and S. Sriragavi, 2018. MER based Bi-directional three widing Dc-Dc converters with ZVS. Intl. J. Sci. Res. Rev., 7: 9-17.

Ramkumar, M.S., M.S. Krishnan and A. Amudha, 2017a. Impedance source inverter and permanent magnet synchronous generator for variable speed wind turbine. Int. J. Comput. Math. Sci., 6: 98-105.

Ramkumar, M.S., M.S. Krishnan and A. Amudha, $2017 \mathrm{~b}$. Resonant Power Converter Using GA for PV applications. Int. J. Electron. Electr. Comput. Syst., 6: 239-245.

Ramkumar, S., A. Elakkiya and G. Emayavaramban, 2014a. Data transfer model-tracking and identification of data files using clustering algorithms. Int. J. Latest Technol. Eng. Manage. Applied Sci., 3: 13-21.

Ramkumar, S., G. Emayavaramban and A. Elakkiya, 2014 b. A web usage mining framework for mining evolving user profiles in dynamic web sites. Int. J. Adv. Res. Comput. Sci. Software Eng., 4: 889-894.

Ramkumar, S., K.S. Kumar and G. Emayavaramban, 2016. EOG signal classification using neural network for human computer interaction. Int. J. Control Theory Applic., 9: 223-231.

Ravichandran, R., K. Balachander, A. Amudha, M.S. Ramkumar and S. Kuppusamy, 2017. Estimation of electrical parameter using fuzzy logic controller based induction motor. Int. J. Control Theory Applic., 10: 205-212.

Sangeetha, R.S. and K. Balachander, 2016. Unbalanced and over current fault protection in low voltage DC bus micro grid systems. Middle East J. Scient. Res., 24: $465-474$.

Shaik, J.B. and S. Babu, 2012. Low crest power factor corrected electronic ballast for fluorescent lamps. VSRD. Intl. J. Electr. Electron. Commun. Eng., 2: $1-10$.

Singh, B. and G.D. Chaturvedi, 2008. Analysis, design, modeling, simulation and development of single-switch AC-DC converters for power factor and efficiency improvement. J. Power Electron., 8: 51-59.

Singh, B., M. Agrawal and S. Dwivedi, 2008. Analysis, design and implementation of a single-phase power-factor corrected AC-DC zeta converter with high frequency isolation. J. Electr. Eng. Technol., 3: 243-253.

Singh, S., B. Singh, G. Bhuvaneswari and V. Bist, 2015. Power factor corrected zeta converter based improved power quality switched mode power supply. IEEE. Trans. Ind. Electron., 62: 5422-5433.

Sivakumar, N., D. Kavitha, M.S. Ramkumar, V. Bhavithira and S. Kalaiarasi, 2017. A single stage high gain converter for grid interconnected renewable application using perturb and observe. Int. J. Control Theory Applic., 10: 161-175.
Sownthara, M. and M.S. Ramkumar, 2016. Wireless communication module to replace resolver cable in welding robot. Int. J. Adv. Inform. Sci. Technol., 23: 230-235.

Sriragavi, S., M.S. Krishnan and M.S. Ramkumar, 2017. Static compensator in power quality improvement for LVTS. Intl. J. Sci. Res. Rev., 6: 51-60.

Subramanian, M., M.S. Ramkumar, A. Amudha, K. Balachander and D. Kavitha, 2017. Power quality improvement in low voltage transmission system using static compensator. Int. J. Control Theory Applic., 10: 247-261.

Sudhakar, R. and M.S. Ramkumar, 2016. Boosting with SEPIC. Int. J. Eng. Sci., 3: 14-19.

Tao, H., J.L. Duarte and M.A. Hendrix, 2008. Line-interactive UPS using a fuel cell as the primary source. IEEE. Trans. Ind. Electron., 55: 3012-3021.

Tse, C.K., 2003. Circuit theory of power factor correction in switching converters. Intl. J. Circuit Theory Appl., 31: 157-198.

Vijayalakshmi, V.J., C.S. Ravichandran and A. Amudha, 2014a. Predetermination of higher order harmonics by dual phase analysis. Intl. J. Appl. Mech. Mater., 573: 13-18.

Vijayalakshmi, V.J., C.S. Ravichandran and A. Amudha, 2014b. SHE in multilevel inverters by dual phase analysis. Aust. J. Basic Appl. Sci., 8: 292-298.

Vijayalakshmi, V.J., C.S. Ravichandran and A. Amudha, 2015. Dual phase analysis based linear regression trained neural network for selected harmonic elimination in a multilevel inverter. Intl. J. Appl. Eng. Res., 10: 6651-6658.

Vuthchhay, E. and C. Bunlaksananusorn, 2008. Dynamic modeling of a Zeta converter with state-space averaging technique. Proceedings of the 5th International Conference on Electrical Engineering/ Electronics, Computer, Telecommunications and Information Technology Vol. 2, May 14-17, 2008, IEEE, Krabi, Thailand, ISBN:978-1-4244-2101-5, pp: 969-972.

Wei, H. and I. Batarseh, 1998. Comparison of basic converter topologies for power factor correction. Proceedings of the IEEE International Conference on Southeastcon '98, April 24-26, 1998, IEEE, Orlando, Florida, USA., pp: 348-353.

Yuvaraj, R., K. Balachander, A. Amudha, S. Kuppuamy and M.S. Ramkumar, 2017. Modified interleaved digital power factor correction based on the sliding mode approach. Int. J. Control Theory Applic., 10: 225-235. 